\title{
OTRI8. SECRETOME ANALYSIS OF CHLAMYDOMONAS REINHARDTII MICROALGAE IN RESPONSE TO AUTOPHAGY INDUCING CONDITIONS.
}

Freire, D.P.B.'; Costa,T.D.2; Santos Silva, G.²; Aguilar, C..; Zingali, R.B.2; Rodrigues, S.P2.

${ }^{1}$ Bio-Manguinhos; IBqM - UFRJ;

${ }^{2}$ IBqM - UFRJ; Pólo Xerém - UFRJ;

${ }^{3}$ The University of Texas MD Anderson Cancer Center.

INTRODUCTION Chlamydomonas reinhardtii ( $\mathrm{Cr}$ ) microalgae secretes extracellular vesicles (EVs) but factors affecting $\mathrm{EV}$ s formation and release are unknown. In mammals, these processes are associated with autophagy. In $\mathrm{Cr}$, autophagy is triggered by nitrogen deprivation and exposure to rapamycin. However, the correlation between autophagy and EVs formation in photosynthetic cells is unexplored.

OBJECTIVE Evaluate the effects of nitrogen deprivation and rapamycin exposure on $\mathrm{Cr}$ protein secretion.

METHODOLOGY A prediction of $\mathrm{Cr}$ proteins potentially secreted in EVs using 23,000 non-redundant protein sequences known to be present in other organisms' EVs (EVpedia database) to interrogate the $\mathrm{Cr}$ proteome (19,526 sequences from Phytozome v5.5). 3,600 (18.4\% of $\mathrm{Cr}$ proteome) positive blast hits (Cr EVs-predicted proteins, $\mathrm{Cr}-\mathrm{EV}$ s-PP) were obtained. To verify the actual secretion of the Cr-EVs-PP, mid-log phase cc-124 cells were cultured $\left(5.5 \times 10^{6}\right.$ cells $\left./ \mathrm{mL}, \mathrm{n}=3\right)$ in TAP medium $(+\mathrm{N})$, TAP containing $5 \mu \mathrm{M}$ rapamycin $(+\mathrm{R})$ or TAP without nitrogen $(-\mathrm{N})$. After 17 hours, a portion of each culture supernatants obtained by centrifugation were freeze-dried and the other part were ultracentrifuged (EVs secretome) and evaluated by Nanoparticle Tracking Analysis (NTA) technique.

RESULTS $\mathrm{Cr}$ derived-proteins accumulated in $-\mathrm{N}(25 \mathrm{mg} / \mathrm{mL})$ and $+\mathrm{R}(3$ $\mathrm{mg} / \mathrm{mL})$ compared to $+\mathrm{N}(<1 \mathrm{mg} / \mathrm{mL})$. 10\% SDS-PAGE protein separation and Sypro Ruby staining revealed complex electrophoretic profiles of proteins ranging from 250 to $20 \mathrm{kDa}$. Preliminary in gel trypsin protein digestion and LC-MS/MS allowed the confident (at least 2 peptides, $\mathrm{P}<0.05$, FDR $<1 \%$ ) identification of 24 
proteins in $+\mathrm{R}$, and 38 proteins in $-\mathrm{N}$ samples, out of which 13 and 12, respectively, are $\mathrm{Cr}-\mathrm{EV}$ s-PP including the EVs' marker HSP70A. The NTA revealed a higher number of 90 to $100 \mathrm{~nm}$ particles in the supernatant of $+\mathrm{R}\left(3.8 \times 10^{8}\right.$ part $\left./ \mathrm{mL}\right)$ compared to $-\mathrm{N}$ $\left(5.8 \times 10^{7} \mathrm{part} / \mathrm{mL}\right)$ and $+\mathrm{N}(6.0 \times 107 \mathrm{part} / \mathrm{mL})$ cultures.

CONCLUSION The supernatant of $\mathrm{Cr}$ cultures deprived of nitrogen or supplemented with rapamycin presented more proteins than control cultures. The NTA suggested more exossomes (90 to $100 \mathrm{~nm}$ particles) in the supernadant of $+\mathrm{R}$ than $-\mathrm{N}$ and $+\mathrm{N}$ cultures. The correlation between autophagy and EVs formation have been indicating proteins, which can open up new possibilities for biotechnological research in Chlamydomonas. The proteomic analysis of TAP, TAP+Rap and TAP-N is still in progress.

KEYWORDS algae, secretome and vesicles. 